BNL - 52556

\title{
BROOKHAVEN NATIONAL LABORATORY WILDLIFE MANAGEMENT PLAN
}

\author{
Dr. J.R. Naidu
}

September 22, 1999

Environmental Services Division

\author{
Brookhaven National Laboratory \\ Operated by \\ Brookhaven Science Associates \\ Upton, NY 11973 \\ Under Contract with the United States Department of Energy \\ Contract Number DE-AC02-98CH10886
}




\section{DISCLAIMER}

This report was prepared as an account of work sponsored by an agency of the United States Government. Neither the United States Government nor any agency thereof, nor any of their employees, nor any of their contractors, subcontractors or their employees, make any warranty, express or implied, or assumes any legal liability or responsibility for the accuracy, completeness, or any third party's use or the results of such use of any information, apparatus, product, or process disclosed, or represents that its use would not infringe privately owned rights. Reference herein to any specific commercial product, process, or service by trade name, trademark, manufacturer, or otherwise, does not necessarily constitute or imply its endorsement, recommendation, or favoring by the United States Government or any agency thereof or its contractors or subcontractors. The views and opinions of author's expresses herein do not necessarily state to reflect those of the United States Government or any agency thereof. 


\section{ACKNOWLEDGMENTS}

Dr. Jan Naidu of Brookhaven National Laboratory (BNL) was the primary author of this plan. This Wildlife Management Plan was prepared with input provided by the New York State Department Environmental Conservation (NYSDEC) Natural Resources Division, Stony Brook staff, New York.

Peer review was provided by Professor J. Black, Suffolk Community College, Selden, NY; J. Brower, Environmental Restoration Division (ESD), Brookhaven National Laboratory (BNL); E.A. Flores, Manager, Environmental Services Division (ESD/BNL)); Dr. T.Green, U.S. Department of Energy (DOE), PANTEX

Site, Amarillo, TX; R. Lee (ESD/BNL); W. Medeiros, (ERD/BNL) and E. Murphy, Plant Engineering (PE/BNL).

M. Daum, ERD, produced the map on "Protected Areas for Endangered Species".

Pine Barrens Commission (PBC) Staff and BNL Staff produced the map on BNL's Natural Resources Inventory.

This report was typed, corrected and formatted by Rosemary Taylor.

BROOKHAVEN NATIONAL LABORATORY

WILDLIFE MANAGEMENT PLAN 


\section{EXECUTIVE SUMMARY}

The Brookhaven National Laboratory (BNL) Wildlife Management Plan describes programs to integrate stewardship of natural resources with Laboratory operations. The Plan outlines the environmental baseline and develops a natural resource management strategy. This Plan was written with input from the NYS Department of Environmental Conservation (NYSDEC), Wildlife Branch.

BNL's wildlife management strategy includes identification of Endangered or Threatened Species and mapping. Surveys are proactively conducted to review and update the current flora and fauna species list. Habitat protection or enhancement activities include, for example, observing tiger salamander breeding success through egg mass and larval numbers. Monitoring is conducted to evaluate impacts of Laboratory operations on the ecosystem. Population management and compliance assurance activities are focused on, for example, deer population control where a number of options are being evaluated. Education, public outreach and research also play an important role in addressing public concerns and is achieved by tours of the site, adult and student participation in environmental programs, and active participation in Federal, State and Local environmental protection committees.

The plan places special emphasis on the endangered tiger salamander and the Species of Special Concern, the banded sunfish, by instituting focused programs that monitor, protect and enhance their habitat to sustain and promote population growth. Activities that have the potential on impacting these two species are subjected to extensive review, and NYSDEC is consulted as necessary.

Reports on the status and implementation of the Plan are required annually. An action plan with schedules for surveys, reporting and activities that will be instituted to protect the ecosystem is also included. This Plan is subject to annual review. New management initiatives will be incorporated as appropriate during each review. The Plan will be revised, as necessary, every three years. 


\section{Table of Contents}

Page

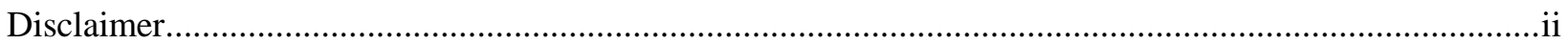

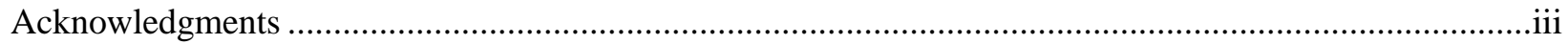

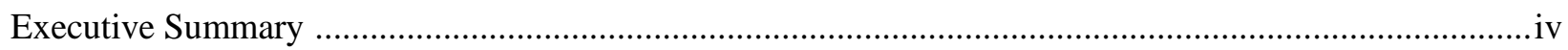

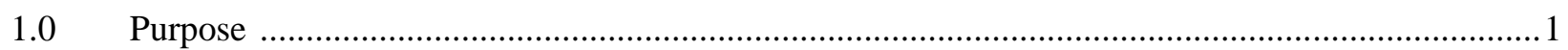

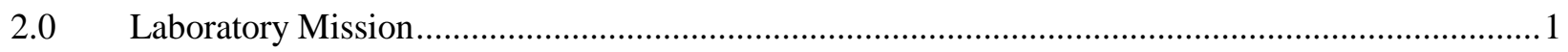

3.0 Wildlife Management Plan Program Drivers.....................................................................

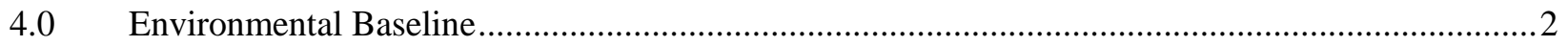

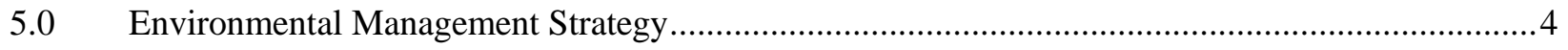

5.1 Identification of Endangered or Threatened Species and Mapping ................................ 4

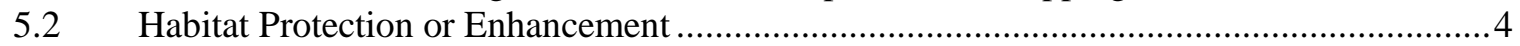

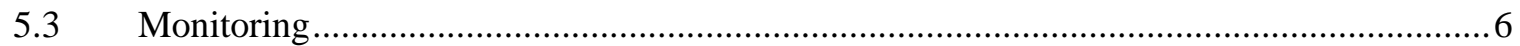

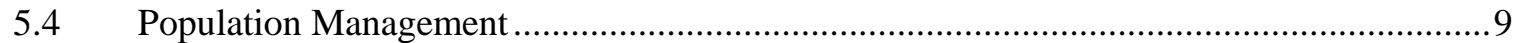

5.5 Compliance Assurance and Potential Impact Assessment ................................................ 9

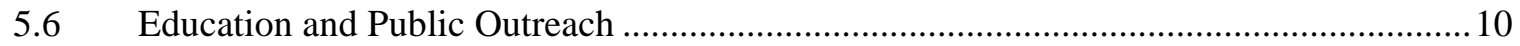

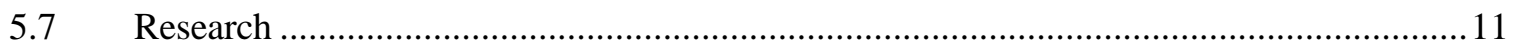

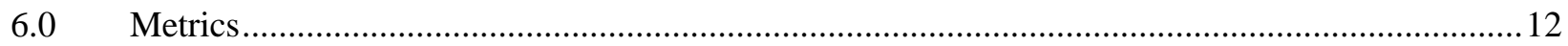

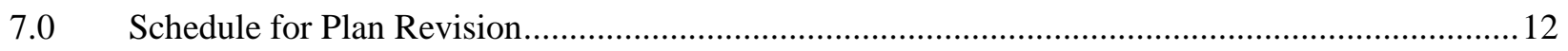

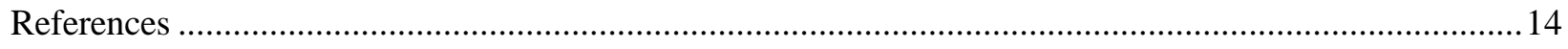

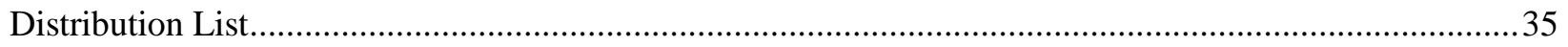




\section{Table of Contents \\ Attachment $A$ \\ Tiger Salamander Habitat Management Plan}

Page

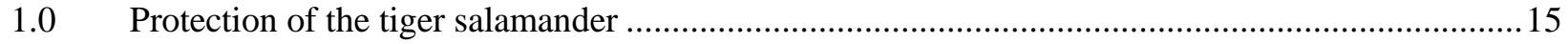

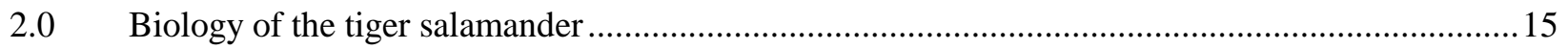

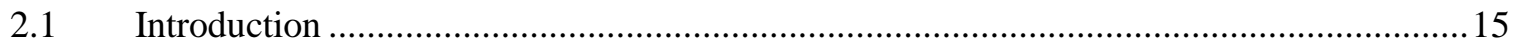

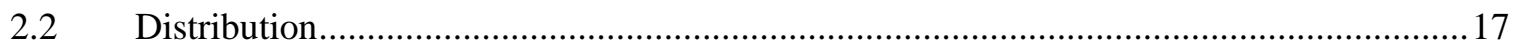

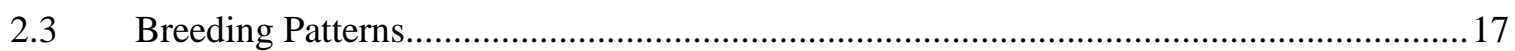

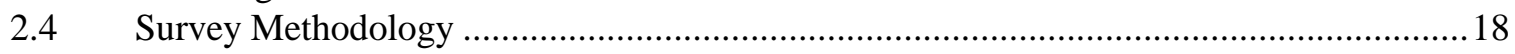

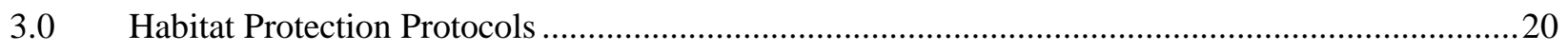

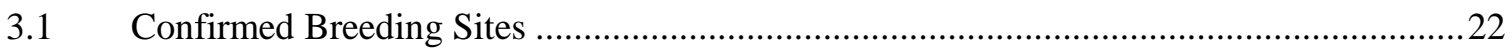

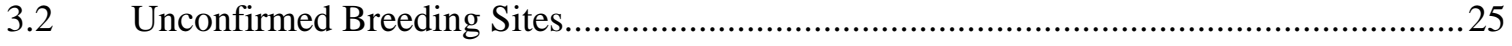

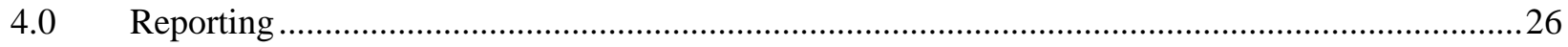

Attachment B

Protection of Species of Special Concern

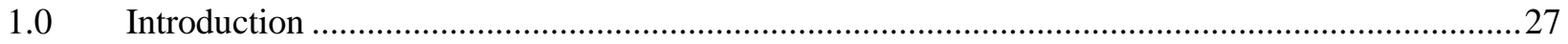

2.0 Banded Sunfish Habitat Protection or Enhancement ..............................................................2

Attachment C

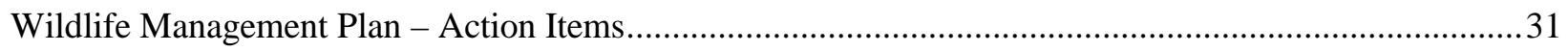

\section{Attachment D}

Plant Engineering Digging Permit. 


\section{List of Figures}

Page

Figure 1. Map of Brookhaven National Laboratory .................................................................

Figure 2. Natural Resources Inventory for

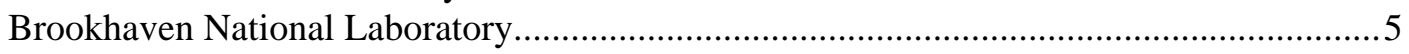

Figure 3. Tiger Salamander (NYS - Listed Endangered Species) ................................................. 16

Figure 4. Protected Areas for Endangered Species .................................................................. 19

Figure 5. Banded sunfish (NYS - Listed “Special Concern” Species ...............................................29

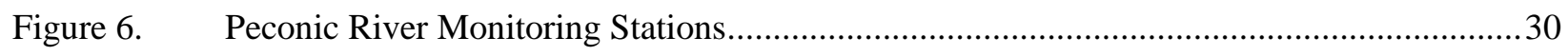




\section{BROOKHAVEN NATIONAL LABORATORY}

\section{Wildlife Management Plan}

\subsection{Purpose}

The purpose of the Wildlife Management Plan (WMP) is to promote stewardship of the natural resources found at the Brookhaven National Laboratory (BNL), and to integrate their protection with pursuit of the Laboratory's mission.

\subsection{Laboratory Mission}

BNL is a multi-program national laboratory operated by Brookhaven Science Associates ${ }^{1}$ for the U.S. DOE. BNL was founded in 1947, and is located on land formally operated as Camp Upton, an U.S. Army facility. BNL is in Suffolk County, New York (NY), and approximately 60 miles east of New York City.

The Laboratory's broad mission is to produce excellent science in a safe, environmentally responsible manner with the cooperation, support and appropriate involvement of our many communities. Specifically, the mission of BNL, which supports the U.S. DOE's strategic missions, is to:

- $\quad$ Conceive, design, construct and operate complex, leading edge, and user-oriented facilities.

- $\quad$ Carry out basic and applied research in long-term programs at the frontier of science.

- Develop advanced technologies that address national needs and initiate their transfer to other organizations and to the commercial sector.

- Disseminate technical knowledge to educate new generations of scientists and engineers, to maintain technical currency in the nation's workforce, and to encourage scientific awareness in the general public.

BNL makes its unique facilities, technical expertise, and the natural environment within its facility available to state and federal agencies, universities, and the private sector to conduct research in a manner that is consistent with these missions.

\footnotetext{
${ }^{1}$ Brookhaven Science Associates is a limited liability company with two principals: the Research Foundation of the State University of New York on behalf of SUNY at Stony Brook and Battelle Memorial Institute.
} 
It is BNL's policy to integrate environmental stewardship into all facets of the Laboratory's missions. $\mathrm{BNL}$ is committed to managing its programs in a manner that protects the ecosystem.

There are also a number of federal, state and local regulations and statutes relevant to wildlife and wetland management. These include the federal statutes, such as the National Environmental Policy Act (NEPA), Clean Water Act, National Emission Standards for Hazardous Air Pollutants, National Historic Preservation Act, Archaeological Resources Protection Act, Suffolk County Sanitary Codes, New Source Performance Standards, Superfund Amendments and Reauthorization Act, Endangered Species Act, and state laws, such as the New York State Environmental Conservation Law (ECL).

Since BNL occupies five percent of the 100,000-acre Central Pine Barrens, the site is also subject to the Long Island Pine Barrens Protection Act of 1995. This act requires preparation of a Pine Barrens Management Plan. The Pine Barrens Commission (PBC) prepared such a Plan in 1996. Since this Act does not have its origin in a federal statute, federal facilities are not subject to this requirement. However, a Future Land Use Plan (BNL 1995) was developed with considerable stakeholder and the PBC involvement. The plan does not preclude future development which may take place in pursuit of BNL's missions, but recommends that the majority of BNL's undeveloped lands be maintained as open space.

\subsection{Environmental Baseline}

Brookhaven National Laboratory covers 5,265 acres (See Figure 1). Approximately 1, 700 acres have been developed near the center of the site. The topography consists of gently rolling terrain with elevations 43.6 to 120.1 feet above sea level within the western rim of the Peconic River watershed.

The site is situated in a deep flow recharge area for Long Island's sole source aquifer system. Soils are generally porous although some low-lying areas have clay accumulations and have formed wetlands. Six major state and/or federally regulated wetlands exist at BNL, with several additional small pocket wetlands situated along the northern and eastern portions of the property. Vegetation on site is in a variety of successional stages due to such past influences as land clearing, fire, local flooding, draining, and artificial plantings.

Environmental studies conducted at BNL by the U.S. Fish and Wildlife Service, the NYSDEC, the United States Geological Survey (USGS), and recently by Lawler, Matusky and Skelly (LMS 1995), have mapped several wetland areas, have identified 230 plant species, 85 avian species, ten reptilian species, nine amphibian species, 15 mammalian species, nine fish species, and identified 13 confirmed breeding sites for the NYS endangered eastern tiger salamander (Ambystoma tigrinum), and identified a resident population of the NYS "Special Concern" species, the banded sunfish (Enneacanthus obesus) in several sections of the Peconic River on-site. Occasional transient individuals of federal and state 
Figure1: Map of Brookhaven National Laboratory

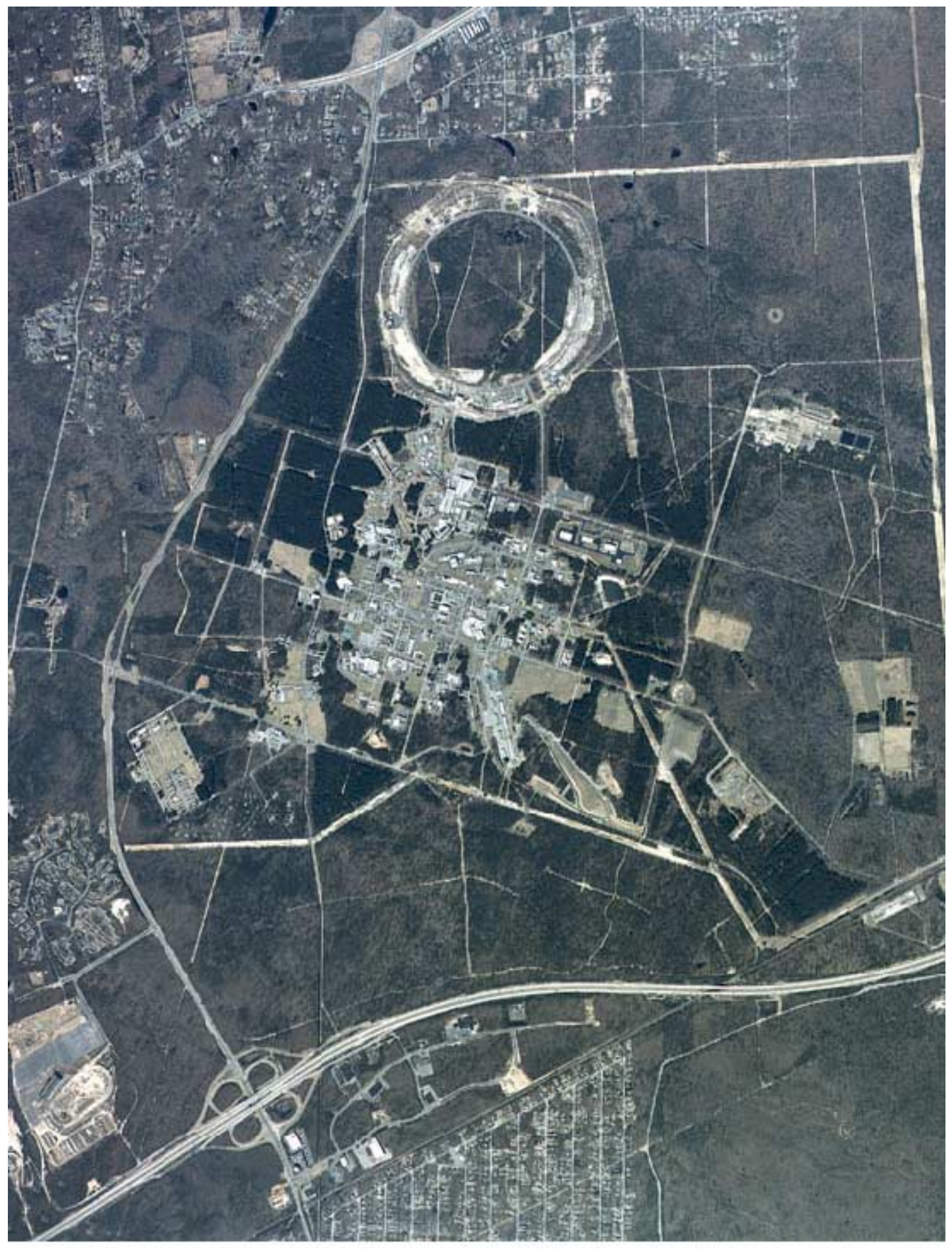


listed endangered species utilize the BNL site for resting and feeding during migration including several raptors, including the peregrine falcon (Falco peregrinus), and various species of owls [sawwhet (Aegolius acodicus); short eared (Asio flammeus); great horned (Bubo virginianus); screech (Otys asio); barred (Strix varia)] . In addition, these studies have further identified twelve plant species (including seven fern species) found on-site to be protected under NYS ECL15 ecological communities on or adjacent to BNL and, within the Peconic river corridor on-site, more than 20 interrelated plant communities have been identified and their locations mapped (Inoue and Naidu, 1986). BNL lands also provides diverse habitat for a host of other wildlife species, which, while not listed as endangered, threatened, or 'species of special concern,' are important to a viable ecosystem. A sitewide biological inventory has been prepared as part of this effort (LMS 1995). This document details the affected environment and wildlife utilization within a 3.2-mile radius of BNL.

\subsection{Environmental Management Strategy}

BNL's wildlife management strategy is based on compliance assurance, ecosystem protection, research, communication, and environmentally responsible development in support of BNL's

missions. The elements of the strategy are summarized below. In some cases, a bulleted list of specific planned actions associated with each program element is provided. Programs designed to protect the endangered species and Species of Special Concern that have been identified on the BNL site are outlined in Attachments A and B, respectively. Specific actions in support of this strategy are summarized in Attachment C.

\subsection{Identification and Mapping of Natural Resources}

An understanding of the environmental baseline, as discussed in Section 4.0 of this plan, is the starting point in wildlife management planning. The PBC conducted a natural resources inventory of the BNL site, based on data collected from 1970 to 1990 (Cooperrider, A., and et al. 1986). This mapping process identified environmentally sensitive areas, significant communities, etc. Currently, two sites within the Relativistic Heavy Ion Collider (RHIC) area have been identified and are considered as important since they will be used to study "atypical" succession, which may, in fact be "typical" for Long Island.

The PBC and BNL are currently re-evaluating the map generated from this effort (see Figure 2 ) in light of new information from various agencies. PBC is planning to generate an updated map pursuant to the Pine Barrens Management Plan.

\subsection{Habitat Protection or Enhancement}

Once habitats that are sensitive or critical to species protection have been identified, programs are developed to protect those habitats, particularly during periods (e.g., breeding) critical to species survival. Activities or projects that could impact those habitats are evaluated (e.g., pollutant discharge, construction activities). An example of this is limiting and controlling the use of pesticides through a site-wide training 
Figure 2: Natural Resources Inventory for Brookhaven National Laboratory

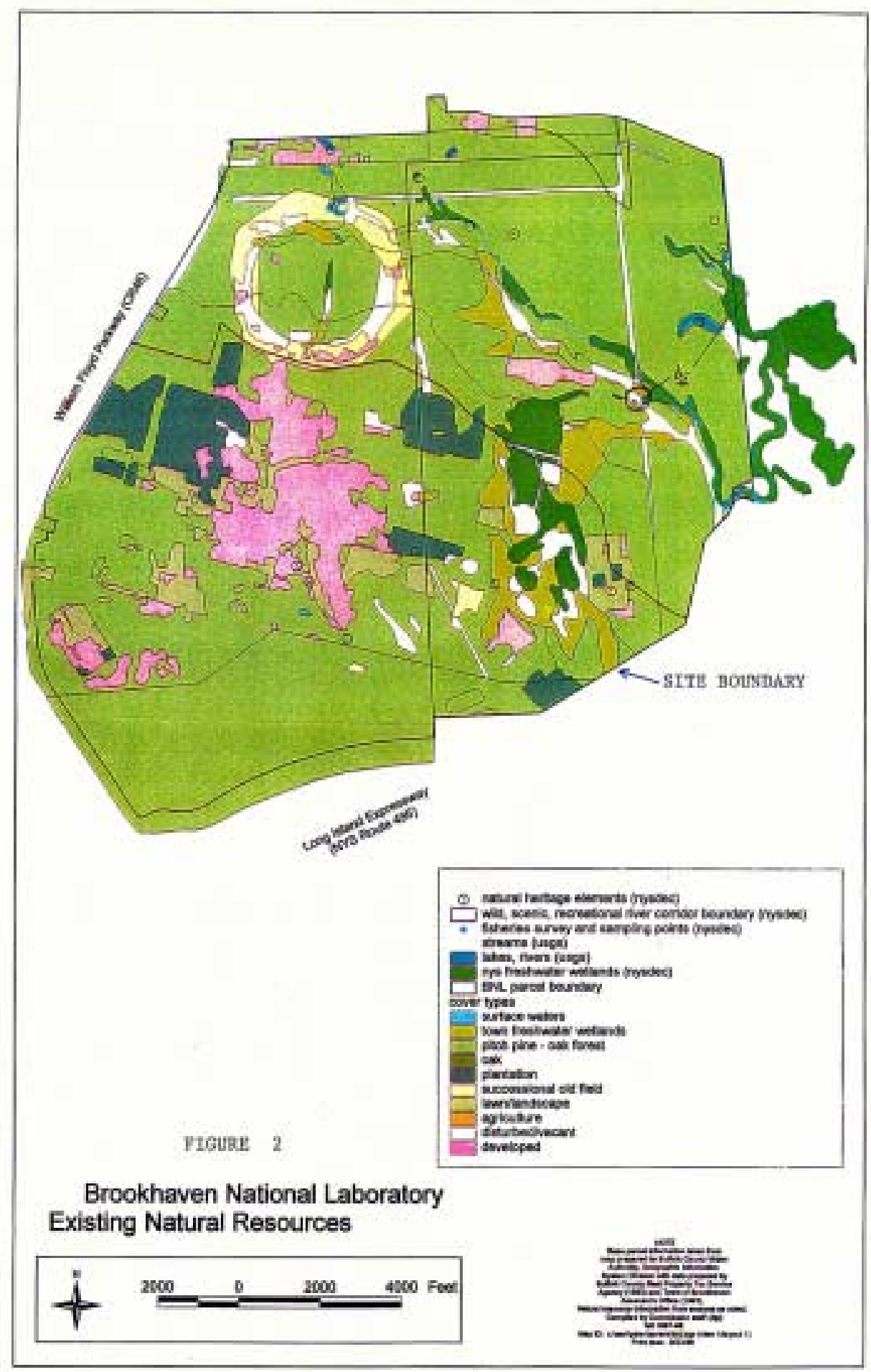

Page 5 
and application program. Appropriate actions to eliminate or minimize negative impacts are either incorporated into BNL procedures or incorporated into specific project plans. For example, the Laboratory has a brush fire control program that addresses the measures taken through training and equipment to prevent and control brush fires. The site is also crisscrossed with firebreaks which are routinely maintained by the Plant Engineering staff as required by the Emergency Response Program. Environmental restoration efforts remove sources that could pollute habitats. Access to critical habitats is restricted. Locations of endangered species breeding populations are maintained as confidential. Routine activities (e.g., road maintenance) that are not expected to impact habitats are allowed to proceed. BNL does not propose to interfere with natural succession through the use controlled burns. In some cases, habitats will be enhanced to improve survival or increase populations of desirable species whose populations have dwindled due to development or habitat destruction on Long Island, even if they are not threatened or endangered.

Near-term activities planned in support of habitat protection or enhancement include the following:

- $\quad$ Adequate water bodies have been retained to provide landing sites and/or breeding sites for Canada goose (Branta canadensis) and other migratory birds.

- In order to attract birds, bird-nesting boxes are being refurbished. New osprey (Pandion haliaetus) platforms are being installed through the BNL Office of Education student and teacher cooperative programs.

- $\quad$ Programs are being identified, planned and implemented in association with the PBC to protect open spaces, for example, the preparation of a site-wide natural resources inventory map (see Figure 5) and its upcoming revision.

- Disturbed areas are being revegetated with natural grasses to provide a diverse habitat.

- Revegetation is being promoted through the GLOBAL ReLEAF program. In 1998, 15,000 pine trees (Pinus rigida) were planted on-site by volunteers and school children.

\subsection{Monitoring}

BNL has an environmental monitoring program designed to determine what impact, if any, the Laboratory operations have on the environment. Under the monitoring program, air, surface water, groundwater, soil and sediment, and terrestrial and aquatic flora and fauna are sampled and analyzed. This data is used to determine whether corrective actions are needed.

\subsubsection{Cesium-137 (Cs-137)in Deer Meat}

- $\quad$ Based on data collected since 1992, meat from white-tailed deer

(Odocoileus virginianus) samples collected on-site has shown concentrations of Cs-137 that are above background (1992-1997 Annual Site Environmental Report).A recent evaluation by NYSDEC Wildlife Branch and the NYS 
Department of Health concluded that the level of Cs-137 in meat does not pose a risk to human health when such meat is consumed (Bureau of Environmental Radiation Protection, NYSDOH March 1999). (Note: Hunting has never been allowed at the BNL site, for security reasons. Although deer have a limited range of approximately one mile, according to the NYSDEC—-some do move off-site.

- $\quad$ The NYS study also concluded that the elevated levels should not impact deer health.

- Monitoring of soil, vegetation and deer meat from onsite locations over the past several years indicates that the Cs-137 concentration levels are decreasing. This decrease is expected to continue with time due to natural radioactive decay, as no new Cs-137 is being added to the environment.

- Contaminated areas are being addressed (phyto-remediation to remove contaminants, soil removal, immobilizing contaminants) under the environmental restoration program.

- BNL has been exploring a number of avenues to control Cs-137 levels in deer. These are:

- Fencing of contaminated areas. Fencing a large areas presents logistical problems, is costly, and deer can readily scale or go underneath fences.

- Revegetation of contaminated areas with non-desirable species of vegetation.

- Providing non-radioactive contaminated feed. This option presents problems in that the existing deer population is already excessive.

- $\quad$ Use of fertilizers to block Cs-137 uptake by vegetation.

- Use of salt licks impregnated with specific chemicals that prevent the transfer of Cs-137 from the digestive track to the flesh in deer. This option would require a research permit, as the use of salt licks is generally prohibited by NYSDEC.

These options will be evaluated for effectiveness, feasibility and cost relative to risk.

5.3.2 Population densities are also monitored.

- The deer population on-site was estimated in 1992 (Thomlinson and Naidu). Since then, the on-site population has apparently increased, in part probably due to land clearing in areas adjacent to BNL. A current population study to estimate the deer population is planned.

- The Laboratory is assisting the NYSDEC in monitoring of wild turkey (Meleagris gallopavo) population on-site. BNL has been working with NYSDEC to observe the wild turkey population distribution on-site. This species was introduced in areas adjacent to the Laboratory in 1996. Since then, significant migration of wild turkeys on to the BNL site has occurred. Monitoring this population on-site helps assess the success of this introduction. Monthly population siting reports are being provided to NYSDEC. 
- $\quad$ BNL staff has held discussions with NYSDEC, and are addressing concerns over amphibian population declines, migratory bird breeding habitats, resident Canada geese populations, and the status of a number of the regions reptilian species. (See section 5.7).

\subsubsection{New Habitat Enhancement Program}

A number of habitat enhancement programs are being planned for FY2000. These are:

a. Conduct a songbird survey. A preliminary survey was conducted in July 1999 . This will be the basis for a site-wide survey to be conducted in April/May 2000. This study will identify species on-site. It will also identify areas where the habitat can be enhanced to attract songbirds. For example, habitats for songbirds that reside in trees could be enhanced by reducing the underbrush growth, and in areas where under-brush is critical for nesting, trees will be cleared or reduced in intensity to facilitate bird nesting.

b. Initiate a simple trapping program around known tiger salamander habitats to study the migration of adult salamanders to the breeding site, and study the migration of adults and juveniles (after metamorphosis) from the breeding site. This study will aid in understanding migration patterns on-site and in plans to enhance the habitat of tiger salamanders and promote more successful population growth. This project will be implemented in late fall, when adults migrate to the ponds for breeding.

c. Comprehensive Revegetation Plan (CRP) for RHIC has been developed (September 30, 1999). Plans for implementation of this plan are being drawn up. When complete the RHIC area will be returned to, a significant extent, the prevalent native vegetation that was present before construction of the RHIC area was begun.

\subsection{Population Management}

BNL also has programs to manage populations to ensure that they are sustainable, and to control undesirable species. BNL is in the process of evaluating options for controlling deer populations on-site. The 1992 study indicated that the population of deer on-site exceeded 700. Normally a population density of 20 to 30 per square mile is considered an optimum sustainable level for a given area. However, since the BNL site has a population density of about 100 per square mile, the need to initiate population control at the BNL site must be considered. Since over population affects animal health and also results in increased property damage and traffic accidents as animals forage into developed areas for food, a number of options is being evaluated for feasibility and effectiveness. All options require a thorough evaluation prior to implementation, and community involvement would be planned if measures such as population culling were recommended. Undesirable predator populations may also be managed. For example, pickerel (Esox niger) and large mouth bass (Micropterus salmoides) are removed from banded sunfish habitat during sampling (see Attachment B, Section 2.0) With regard to 
vegetation, attention is being focused on the invasive species such as phragmities (Phragmites australis), which are known to destroy native vegetation along water bodies and can potentially threaten endemic aquatic species.

\subsection{Compliance Assurance and Potential Impact Assessment}

BNL is committed to achieving compliance with applicable environmental requirements. BNL's NEPA program is key to ensuring that environmental impacts of a proposed action are adequately evaluated and addressed. BNL will continue to use NEPA, or NEPA equivalence under the Comprehensive Environmental Response, Compensation and Liability Act (CERCLA) program, as the process to identify potential environmental impacts associated with various activities (especially physical alterations). A site-wide Environmental Impact Statement (EIS) for BNL was prepared in 1977 under NEPA, and environmental assessments have been conducted for the Booster, RHIC, and the new Hazardous Waste Management Facility. As appropriate, stakeholders, such as the Environmental Protection Agency (EPA), NYSDEC, Suffolk County Department of Health Services (SCDHS), The Nature Conservancy, the Town of Brookhaven, the Citizens Advisory Board, and local environmental groups, etc., are involved in the review of projects with a potential to significantly impact the environment.

Impacts to the environment can be categorized in several ways. An impact can be the result of a past activity, which was legal at the time; the result of a past physical alteration of existing habitats; or an introduction to an environment of an object or species non-native and/or invasive to the area, which can impact the ecological balance of that natural environment.

Impacts to the environment resulting from past activities (e.g., environmental contamination) are presently being evaluated and action plans to mitigate these impacts are developed by BNL's Environmental Restoration (ER) program.

Impacts to the environment resulting from past physical alterations include such actions as BNL's meadow marsh investigation, the gamma forest experiment, excavation of recharge basins, mosquito ditching, and construction of the RHIC. In

many instances these alterations have benefitted local fish and wildlife. Some excavations and artificial wetlands are now utilized by the eastern tiger salamander

as breeding pools. Installation of bird boxes has provided nesting habitat for the eastern bluebird (Sialia sialis). The gamma forest experiment and subsequent revegetation studies of the same area have increased our understanding of the environment.

Examples of introduction of non-native species or change in species composition due to natural and/or anthropological actions are as prominent as the white pine (Pinus strobus) stands within the northeastern border of BNL, or as subtle as the existence of largemouth bass (Micropterus salmoides) and various sunfish within some recharge basins. The presence of phragmites and the Japanese knotwood (Polygonum $s p$ ) has demonstrated the effectiveness of such non-native species in dominating and destroying native vegetation, especially those that support endemic bird and insect population. Climatic changes (prolonged drought conditions or above normal rainfall) have impacted flow regimes in recharge basins on-site causing them to dry up and then refill, thereby providing breeding sites for tiger salamanders. Other artificial pools now support monoculture fish species and tiger salamanders. 


\subsection{Education and Public Outreach}

BNL-hosted visitors are educated on the disruptive effects that introduction of non-native species can have on the ecosystem, and also how to prevent such introduction. This educational program is implemented through publication of periodic articles in the Brookhaven Bulletin and through proposed distribution of pamphlets available from the NYSDEC and other local environmental protection groups. Plans are being implemented to provide such pamphlets to all new employees during orientation and they will also be made available to visitors during tour programs in the summer of 1999. Other activities to encourage appreciation of BNL's natural resources, such as summer tours, nature walks, Earth day activities, etc., are regularly planned and available to the community. A copy of this WM Plan is also available on the BNL Web Site. Future plans include developing a webpage on the specific wildlife at BNL, and continuing to provide opportunities for students to conduct ecological studies on-site.

The Community Involvement, Government and Public Affairs program conducts regular tours of the Laboratory site for private citizens, school children, and college students. The ER program, as part of its public outreach program, has a similar program for stakeholders, local, state and federal agencies that focuses on environmental restoration activities. BNL environmental protection program staff have provided presentations on this plan and ecological studies to the Brookhaven Executive Roundtable and other interested community groups. BNL has also collaborated with the Long Island Groundwater Research Institute, State University of New York (SUNY) at Stony Brook and the Pine Barrens Commission in coordinating and hosting the Annual Pine Barrens Research Forum. This Forum has provided a platform to present ongoing research. In addition, through the Speakers Forum and Envoy Program, BNL staff goes to schools, civic organizations, and meet with other interested parties to give presentations on environmental issues and environmental restoration.

\section{$5.7 \quad$ Research}

Ecological research is conducted on-site to update the current natural resource inventory, gain a better understanding of the ecosystem, and guide management planning. Topics that have been or being addressed include:

- $\quad$ Surface water chemistry of the recharge basins and the Peconic River

- $\quad$ The Gamma Forest - 1962 to 1979, and later years - 1997 and 1998

- $\quad$ State and federal wetlands mapping

- $\quad$ Soil mapping

- $\quad$ Phyto-sociological mapping of the Peconic River

- $\quad$ Recruitment of pitch pine (Pinus rigida) and various oak-forest types

- $\quad$ Effects of shrub layer on long term forest structure 
- Identification of areas that may be candidates for restoration through planting of native species, especially in disturbed areas, and thereby controls invasive and exotic species.

Such studies can also support a request to DOE to have parts of the BNL site designated a National Environmental Research Park. This designation would provide an avenue for requesting DOE funding to be used for long term ecological research by universities, schools and interested citizens at the BNL site.

Facilities are being provided to University and High School students to carry out ecological programs as part of their thesis or special projects. Currently, three studies are in progress:

- $\quad$ Population studies of hog-nosed snakes;

- Development of a nature trail (as a teaching tool);

- $\quad$ Revegetation studies in the gamma forest.

BNL is also pursuing implementation of a satellite study under the Global Fiducial Program, in cooperation with the U.S. Fish and Wildlife Service, PBC, National Weather Service and U.S. Geological Survey. This study, which is contingent on funding availability, would cover the 100,000 acres that are part of the Central Pine Barrens. The study would enable BNL scientists to evaluate the impact of BNL operations on the Pine Barrens ecosystem. Data from this study would become part of a Suffolk County GIS database.

\subsection{Metrics}

The success of the Wildlife Management Plan will be measured by the following metrics:

1. Degree of completion of tasks identified in the Action Items List (Attachment C).

2. Results of population counts of tiger salamander done during the biennial survey will provide a measure of use (increase or decrease) of a given pond, and identify whether higher or lower reproductive rates are occurring. Success or failure of a given action will then be used to modify management strategies, as necessary.

3. Results of any external oversight by federal, state and local agencies on the implementation of the Wildlife Management Plan.

4. Timeliness of submission of required reports on environmental issues to regulatory agencies.

5. Number of student programs involving ecological studies on-site, and their contribution to the environmental database.

Documentation of success will be reported in the annual site environmental report. 


\subsection{Schedule for Plan Revision}

The BNL Wildlife Management Plan will be reevaluated and updated either upon discovery/ listing of new threatened or endangered species found to occur on BNL property, or every three years (whichever comes first). The plan will also be revised, as necessary, based on periodic evaluations of its effectiveness. The Environmental Services program will, beginning with calendar year 1999, prepare an annual summary report of activities undertaken as a result of this plan. This report will assess the effectiveness of the Plan, and make recommendations for changes to the programs, including the addition of appropriate initiatives. 


\section{References}

1. Blais, D., 1993. Species dossier on the eastern tiger salamander (Ambystoma tigrinum) NYSDEC Endangered Species Working Group.

2. Breeder, C.M., 1936. The reproductive habits of the North American Sunfishes. Zoological, 21(1): 1 B 48.

3. Breisch, A., 1994. Personal Communication.

4. Brookhaven National Laboratory, Site Environmental Reports, 1972 - 1997.

5. Brookhaven National Laboratory, 1995. Future Land Use Plan. BNL B 62130.

6. Bureau of Environmental Radiation Protection, NYSDOH. Deer Meat Contamination with Cs-137 at Brookhaven National Laboratory, March 1999

7. Cooperrider, A., R. Boyd, and H. Stuart, 1986. Inventory and monitoring of wildlife habitat. US Department of Interior, Bureau of Land Management, 858 pp.

8. Inoue, K., and J. R. Naidu, 1986. Vegetation of the Peconic River, A Phytosociological Survey. S\&EP Division, BNL.

9. Lawler, Matusky \& Skelly, 1995. Phase II Sitewide Biological Inventory Report Operable Unit IV. Office of Environmental Restoration, BNL.

10. McDougal, J., to J. Naidu, letter dated July 7, 1998

11. Madison, D. M., and L. Farrard, 1998. Habitat Use during Breeding and Emigration in Radioimplanted Tiger Salamanders, Ambystoma tigrinum. Copeia 1998 (2), 99. 407 - 410.

12. NYSDEC, 1994. tiger salamander breeding pond protocol. 8pp.13 NYSDEC, 1995. Personal Communication.

13. Thomlinson, W. C., and J. R. Naidu, 1993. Population Estimate of a Closed Deer Herd at Brookhaven National Laboratory. Univ. of Maine and S\&EP Division Internal report. 


\section{ATTACHMENT A}

\section{Tiger Salamander Habitat Management Plan}

\subsection{Protection of the tiger salamander}

The tiger salamander (Ambystoma tigrinum) was officially listed as a state-endangered species in 1983 (NYS ECL, Article 11, Section 11-0535, NYSCRR Title 6, part 182.6). Populations have declined as a result of loss of habitat through development, road mortality during breeding migration, introduction of predatory fish to breeding sites, collection for bait and pet trade, water level fluctuations, pollution, and general disturbance of breeding sites.

The tiger salamander is afforded "protection from habitat destruction, harm or harassment" by NYSDEC. All State-recognized breeding sites and the 500 foot radius buffer zone surrounding each site are considered critical habitat for breeding, and are accorded the highest priority for protection. An additional 350 feet beyond this area is also considered as critical to the resident adult population (Madision and Farrand, 1998). Use of land around the breeding pond buffer zone is subject to State Environmental Quality Review Act proceedings (A. Breisch, NYSDEC 1994), and therefore this 850 foot buffer zone is monitored by BNL, in collaboration with NYSDEC as needed.

\subsection{Biology of the Tiger Salamander}

\subsection{Introduction}

The tiger salamander, an amphibian, is the largest of six mole salamanders (genus Ambystoma) found in New York. These salamanders seem to prefer the sandy, friable soils that are typical of pine-oak communities (Pinus rigida)/(Quercus sp.) on Long Island. However, tiger salamanders are also found in fields, lawns, gardens, and pastures. Tiger salamanders have been historically been recorded from Central Nassau and Jamaica, Queens County, far outside the limits of the Pine Barrens. Both adults and subadults lead a fossorial (underground) existence, foraging for invertebrates, insects, worms, and slugs through their own burrows or existing small-mammal burrows and root-ways (passages created when roots rot away). Occasionally, salamanders may move under leaf litter, through hollow logs or beneath debris. Other mole salamanders potentially occurring in the same habitat include marbled (A. opacum), spotted (A. maculatum), and blue-spotted (A. laterale) salamanders (LMS, 1995). All mole salamanders have similar body configurations: broad, flat heads with protruding eyes, large mouths, thick bodies, and strong legs with thick blunt toes (four front and five rear). Adults are easily distinguished from juveniles by their color patterns and size. Larval salamanders are similar to adult salamanders in body shape, but body size, development, and coloration can usually be used to distinguish between the species (Figure 3). Adult tiger salamanders may live ten to fifteen years in the wild and grow to total lengths of nine to ten inches. Natural predators include short-tailed shrews, fish, snakes, turtles, herons, and shorebirds. Insect larvae may also prey on the early larval stages of tiger salamanders. 
Figure 3: Tiger Salamander (NYS - Listed Endangered Species)

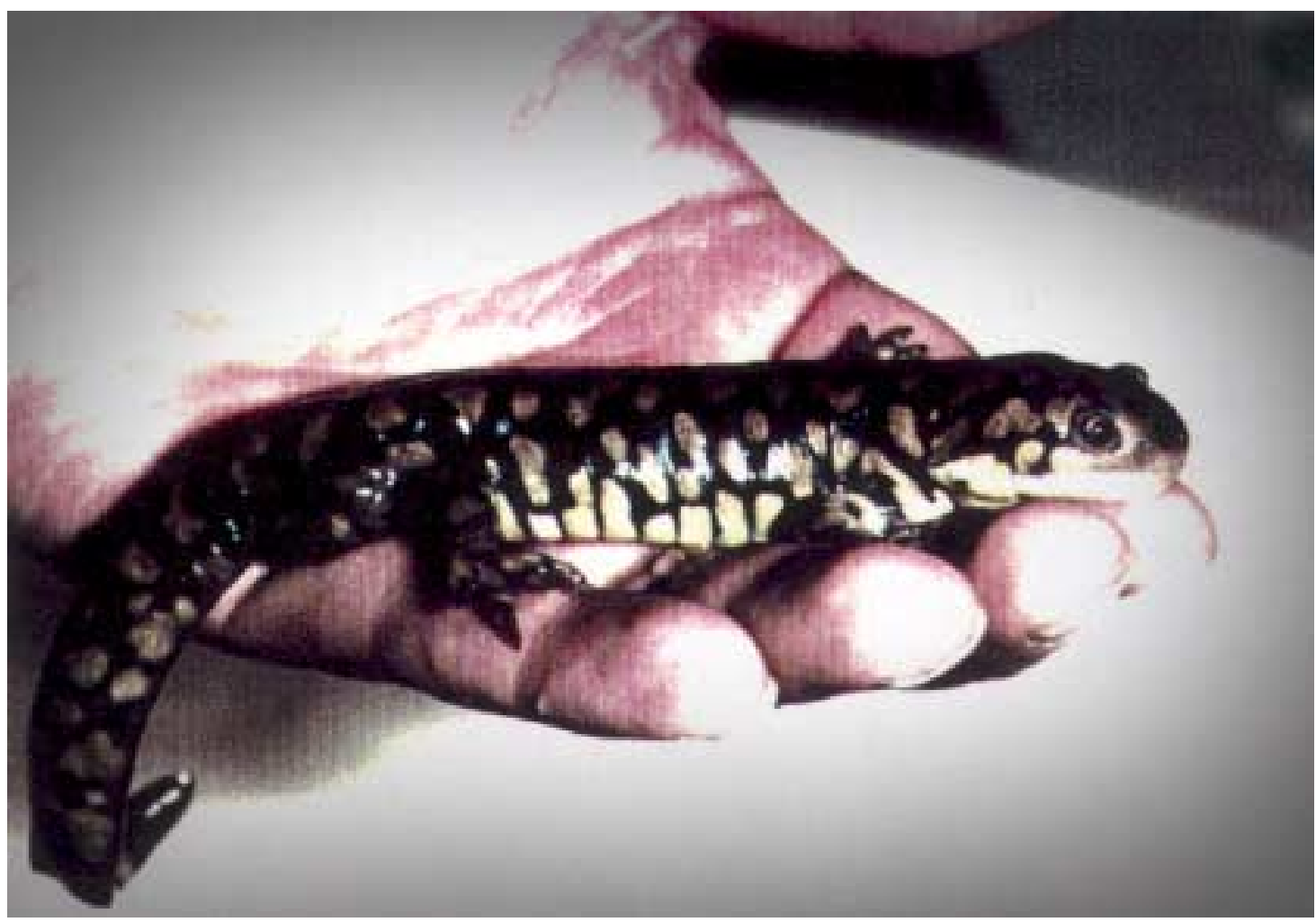

\subsection{Distribution}

In the northeastern United States, tiger salamanders do not occur north of Long Island or in Pennsylvania. South of Long Island, tiger salamanders are found in southern New Jersey, Delaware, and Maryland. The Long Island distribution of tiger salamanders centers around the towns of Brookhaven and Southampton. Since 1984, NYSDEC has confirmed ninety-one active tiger salamander breeding sites on Long Island (Blais 1993), however, since then it has been observed that a number of such sites have been eliminated as breeding sites, except at the Laboratory site, where the largest number of sites were observed. Lawler, Matusky \& Skelly (LMS) confirmed thirteen on-site locations as tiger salamander breeding habitat during 1994 surveys (LMS 1995), whereas NYSDEC previously listed only one area.

\subsection{Breeding Patterns}

In New York, tiger salamanders migrate to breeding ponds as early as mid-January or as late as early April. The timing depends on winter weather conditions, when the possibility of hard rains or snow occurs. Migration usually takes place at night. As with most mole salamanders, rain or melting snow stimulates the adults to emerge from underground retreats and migrate to breeding ponds. Males usually outnumber females and reach the ponds first. Courtship begins when a female encounters one or more males. Males nudge the female and set spermatophores (sperm packets) in the sediment or on sticks and leaves. The female 
maneuvers herself to insert spermatophores into her cloaca, where sperm from the spermatophore fertilize her eggs. Within a few days after fertilization, females lay 200 to 400 eggs in several batches. The eggs are attached underwater to sticks and emergent/submerged vegetation about one foot below the surface of shallow (approximately three feet) ponds. Depending on water temperature eggs hatch in fourteen to thirty days (Blais 1993).

Newly hatched larvae are 0.50 - 0.68 inches long. They metamorphose from mid-June to early August (Blais 1993). The aquatic larvae have fan-like gills, but gradually develop lungs in preparation for a terrestrial adult life. Larval salamanders feed on aquatic invertebrates (insect larvae, copepods), and are known to feed on the larvae of other amphibians. Larvae may undergo early metamorphosis in drying ponds. Mortality is high if the ponds dry up too rapidly. Adults leave the ponds soon after breeding, triggered by favorable weather conditions such as rain or high humidity; sub-adults migrate following transformation.

Based on the above observations, the critical times for the salamander species are as follows:

- December to April for spotted and tiger salamander adults when they are most active, most often above-ground and moving to and from breeding ponds (within the 850 foot "buffer zone" radius).

- $\quad$ May to August for metamorphosis as they leave the ponds and travel to upland shelters (within the 850 feet buffer zone radius).

\subsection{Survey Methodology}

Tiger salamander surveys were conducted in 1994 from March 22 to March 25 (breeding adults), April 5 to April 7 (egg masses), May 16 to May 19 (larvae), and June 6 to June 9 (larvae). Twenty-three locations on the BNL site were checked at least once for adults or egg masses; 17 locations were checked for both adults and egg masses. During May and June, 11 sites were checked for larval tiger salamanders, primarily to verify species identification, which had tentatively been determined, based on size and configuration of egg masses. Survey locations included sites identified by NYSDEC as historical/confirmed or potential tiger salamander breeding habitats. Evaluations of potential habitat were first made on the basis of field and aerial photograph investigations. Figure 4 is a full-scale depiction of the breeding locations. Superimposed on the map, at each confirmed location, an 850 foot (radius) buffer protective zone has been marked. Transmitters attached to tiger salamanders have determined this buffer zone of 850 feet radius to be the area within which tiger salamanders reside and breed (NYSDEC 1995/ Madison and Ferrand, 1998). As previously mentioned, information on tiger salamander pond locations is not public information; hence, this map showing the confirmed breeding ponds will not appear in report copies.

Survey timing was coordinated with NYSDEC as the agency was conducting concurrent tiger salamander studies on Long Island. The first survey for breeding adults commenced when tiger salamanders reportedly began moving to spawning areas in the vicinity of BNL. Subsequent surveys for egg masses and larvae were based on known timing of their life stages. 
Habitats sampled included a variety of natural and man-made wetlands, coastal plain ponds, retention basins, and vernal pools.

The sampling methodology described below was developed from the protocol provided by NYSDEC (1994):

a. Searches for adult tiger salamanders and egg masses were conducted at night from March 22, 1994 to March 25, 1994. Sites were located during the day and surveyed at night in areas up to about three feet deep. Using lights, salamanders were spotted nesting on the bottom and captured using dip-nets. Information on sex and approximate length was recorded. Any egg masses observed were also recorded.

b. $\quad$ Diurnal searches for egg masses were conducted from April 5, 1994 to April 7, 1994. Egg masses were located during the day by wading through sites, and the number found was recorded.

c. Diurnal larval searches were conducted in conjunction with the spring seasonal survey (May 16, 1994 to May 19, 1994) and the breeding adult survey (6-9 June 1994). In May 1994, sites were checked and dip-netted at several possible breeding sites. In early June 1994, sites were checked and dip-netted or seined to collect larvae. Snout-vent and total length of representative larvae were measured. 
Figure 4 is a confidential map with restricted distribution. 


\subsection{Habitat Protection Protocols}

Protection of this species will consist of the following actions.

- $\quad$ Identifying and mapping of tiger salamander habitats.

- As part of the ongoing process to maintain and/or improve the suitability of the tiger salamander habitat and the tiger salamander breeding sites, each site (confirmed or potential) has been reviewed with the NYSDEC staff, during a recent survey conducted in August/September 1998. Suggestions for improvement described below will be implemented in 1999 as funding allows. The schedule for implementation is given in Appendix $\mathrm{C}$ of the Wildlife Management Plan. Figure 4 shows the location of the sites. (Note: This map is confidential, and is not included in Plan copies for general distribution.)

Identifying the period between the times when adult salamanders are migrating toward breeding locations (mid-January or early April), when juveniles and adults are migrating after breeding, and when metamorphosis has been completed. During these times, construction and/or maintenance activities by the laboratory engineering staff will be minimized. An example would be to restrict recharge basin maintenance activities to take place from approximately December to August, in an effort to avoid the tiger salamander breeding and larval developmental periods.

- Water quality testing will be conducted as part of the routine monitoring of the basins. This data will be used to assess the quality of water prior to the breeding cycle.

- $\quad$ Consulting with the NYSDEC for any action impacting known or suspected tiger salamander habitats. This will be coordinated through the Environmental Services program staff. To ensure this action, the Environmental Services, Plant Engineering (PE) and Environmental Restoration (ER) program managers have received a map of known tiger salamander breeding areas (Figure 4), with the understanding that this information will remain confidential. When certain activities are planned within the 850 foot buffer zone, BNL staff will consult with the Environmental Services program, and the NYSDEC as needed, in particular if the proposed action has the potential to significantly impact a confirmed breeding location,. These activities include PE activities, such as: maintenance of recharge basins (e.g., scraping), clearing, grubbing, soil excavation, and other construction activities, and ER efforts (see PE protocol - Attachment D). The purpose of this review is to ensure that the planning activity does not interfere with the breeding or migration activity. It should be noted that when recharge basins are reworked, a part of the basin will be increased in depth to maintain a minimum water level to facilitate breeding in the event a recharge basin needs to be reworked during the breeding cycle window.

- $\quad$ Continuing routine maintenance of roadways (including salting and snow plowing), road shoulders (mowing), fire breaks (annual clearing), and existing operations as these activities pose no direct impact to the breeding pools. However, every effort will be made to conduct these activities before or after the breeding cycle, and to consider potential impacts in surrounding areas during other sensitive stages of the tiger salamander's life cycle.

- $\quad$ Controlling and monitoring the use of pesticides and salt. Pesticide application is tailored to minimize use. Agricultural fields are usually cultivated after the salamanders have completed 
their migration, however, the use of pesticides may require that a monitoring program be initiated to determine if pesticide residues in the water could impact the development of larvae and juveniles. Salting the road during winter and the potential of runoff entering the breeding areas will require monitoring of the runoff to evaluate the impact on larvae and juveniles. Currently, the following water quality parameters are monitored: temperature, $\mathrm{pH}$, dissolved oxygen, conductivity, salinity, chlorides, nitrates, sulfates, and metals. Consideration is being given to adding salinity to the monitoring program to evaluate the impact of salting roads.

- $\quad$ Activities such as providing attachment sites for egg masses will occur during the spring and summer of 1999, through cooperative programs with schools and colleges. The BNL Office of Education Programs administers these programs. Activities that require construction will be referred to the Plant Engineering program for appropriate and timely action.

Beginning in 1999, the Environmental Services program will coordinate a biennial survey of existing and potential tiger salamander habitats. The results of such surveys will pinpoint the length of the breeding period and provide an active window for construction activities in and around the breeding areas, and identify changes in site use and possible activities that could be impacting this species. Based on this survey the Plan will be reevaluated and updated with the discovery and/or listing of new threatened or endangered species found to occur on BNL property and/or every three years, which ever comes first.

ES and NYSDEC staff completed a review of all the sites in August and September 1998, and again in March 1999. All locations were found to be suitable for tiger salamanders, except one. This site was reviewed in late August 1999, and observed to be not suitable as a tiger salamander habitat. Additional surveys will be conducted in late fall (1999) to confirm this. Also in late fall (1999) one of the sites will be chosen to study the migratory behavior of the tiger salamander (see section 5.3.3, page 8). Developing egg masses and larval stages were observed in two of the confirmed sites. This data has been incorporated in the tiger salamander habitat location map, which is included in this plan.

The following describes known or suspected tiger salamander habitat protection plans for confirmed and unconfirmed breeding sites. Note that the NYSDEC has records confirming approximately 107 breeding localities in New York State since 1983-1984. It is unknown how many of these are still active. Some of these populations have been extirpated, and some were apparently never used by large numbers of breeding salamanders. They believe that a relatively small number of sites have confirmed breeding activity every year they are surveyed. Difference in presence/absence observations may be due to biological phenomena or search/observer bias (McDougal to Naidu, July 12, 1998).

A "TS" designation indicates that the site is confirmed; "ts" means unconfirmed; "TS-W" means a wetland site; and, "TS-A" means a man-made pond.

\subsection{Confirmed Breeding Sites}

TS-1 is a vernal pool. This is a suitable habitat for breeding tiger salamanders, although there are few attachment places for egg masses. A number of potential predators are present (as of last survey in March 1994), including bullfrogs, green frogs, painted turtles, and solitary sandpipers. This site will be enhanced as a salamander-breeding habitat by adding 
tree limbs for egg attachment in the deeper sections of the pond.

TS-2 is a vernal pool. This is a suitable habitat for breeding tiger salamanders, although there are few attachment places for egg masses and the pond is used illegally by the public as an All Terrain Vehicle (ATV) racetrack. This pond will be enhanced as a salamanderbreeding habitat by adding more tree limbs for egg attachment in the deeper sections of the pond, and use of this pond for ATV usage will be strictly prohibited. This will be enforced by posting warning signs and through security patrols. A request has been made to the Security program for assistance. Action is pending (See Attachment C).

TS-5, a coastal plain pond, was surveyed for adult tiger salamanders in March 1994, but none were observed. The pond was not surveyed for eggs in April 1994 because of the presence of predatory fish and the lack of adults observed earlier. While seining in this pond in May 1994, two tiger salamander larvae were collected. The most likely limiting factor to salamander breeding is the pond's proximity to neighborhoods and public roads, and the occasional introduction of predatory fish. Since it is adjacent to public property, monitoring of this site may be difficult to conduct. However, special emphasis will be placed on this site during the biennial survey of the site.

TS-6: The water tank pond was the only area on the BNL property identified as a significant habitat by NYSDEC (so designated because of its function as tiger salamander breeding habitat). The observation of several adult males and females, egg masses and larvae attest to this. No actions are recommended at this time.

TS-7 is a retention basin (once a wetland area) that receives surface runoff from a man-made channel. The presence of adult salamander, egg masses and larvae confirm that this retention basin provides breeding habitat for tiger salamanders. There is limited egg mass attachment, potential for significant road mortality during periods of salamander migration, and evidence that the basin receives runoff from a drainage ditch. Routine analyses of this storm water runoff done during the year can be used to determine whether water quality in this pond is affected. Means of improving the basin as salamander habitat include adding suitable egg attachments. The road adjacent to this pond has been blocked off to vehicular traffic because of flooding of the road. Blocking this road has prevented road kills especially during the breeding season. This pond will be checked for predator fish species and their population distribution during spring and summer of 1999, when the NYSDEC staff will conduct fish sampling on-site.

TS-8 is a coastal plain pond. The presence of males, females and egg masses indicates that this pond provides a suitable habitat for tiger salamanders. No actions are recommended at this time.

TS-9 is a sedge depression that becomes an elongated vernal pool by seasonal flooding. Presence of egg masses and larvae indicates that this pond provides a suitable habitat for tiger salamanders. No actions are recommended at this time.

TS-10 is a man-made retention basin. The basin receives run-off from a large drainage ditch (a smaller channel of which drains into TS-7). This basin has the potential of drying up and 
as such would not allow larvae to transform to adult salamanders. In addition, there is a lack of attachment sites in this basin. It also has the potential of becoming polluted due to input from storm water run-off, and may gradually fill with sediments. Prevention of siltation will be achieved by using hay bales or through planting large vegetation swales. Therefore, the basin will be made deeper to allow retention of water for a length of time sufficient for maturation of the larvae. This activity will be conducted in 1999. A dirt road just north of this pond will be retained as a dirt road, as paving would increase usage and therefore road mortalities.

TS-13 is a retention basin. Adult tiger salamanders were found in this basin, however, there was no evidence of egg masses or juveniles. As conditions for breeding are favorable at this site, special attention will be given to this site during the biennial survey.

TS-14: This pool is located in the gamma forest. Though no juvenile tiger salamanders were found in the pool, conditions for breeding are favorable, especially in the wetland pockets that are associated with this pool. Special attention will be given to this site during the biennial survey.

TS-15 is located adjacent to a wetland area and egg masses were noted. Addition of egg mass attachment sites will be completed to improve the pool as a tiger salamander habitat.

TS-W3 is a vernal pool located in a large herbaceous wetland. Presence of adult salamanders, egg masses and larvae confirm this pool is a suitable habitat for tiger salamander breeding. However, the area to the north of this site is developed, and the pool may receive runoff from the road. Addition of egg mass attachment sites to the deepest sections will be completed to improve the pool as tiger salamander habitat.

TS-W4 is a series of small vernal pools. Presence of egg masses and larvae confirm this site as a breeding site for tiger salamanders. Some of the pools are shallow and small (less than two feet deep and less than 50 square feet, in surface area); connecting and deepening these pools would enhance this habitat. Construction of a lined pool in this location is proposed under the ER program. When completed, this could greatly benefit tiger salamanders by improving the breeding site.

TS-A7 contains two man-made retention basins lined with plastic. The presence of adult salamanders (observation by a naturalist) and of egg masses and larvae confirm this as a breeding pond for salamanders. However, the Lawyer, Matusky \& Shelly (LMS) survey (LMS 1995) did not indicate the presence of adults, which could be attributed to the abundance of bullheads (a predator). In the spring and summer of 1999, NYSDEC staff will sample this basin for predator fish. The east basin will provide breeding habitat as long as the integrity of the plastic liner is maintained.

TS-W6b is a vernal pool located within a developed section of the BNL site (across from W6a). Presence of adult salamanders, egg masses and larvae confirms that this pool is a breeding site for tiger salamanders. However, the pond does dry up and may be doing so before the larvae transform to sub-adults. It should be noted that there is a potential of contaminated runoff discharging into this area. This area is consequently being assigned under the ER program. Remediation which is being proposed for this site will prevent any 
contamination entering this vernal pool. Because of this and the fact that the pond sometimes dries up before the larvae can mature, installation of an aboveground pool (with a sloped access ramp) is being proposed as part of the remediation program.

\subsection{Unconfirmed Breeding Sites}

ts-3 and ts-4 are vernal pools located adjacent to confirmed tiger salamander habitats. Although the ponds appear to be undisturbed, with suitable habitat and ample egg attachment sites, no evidence of salamander use was found during the 1994 survey. As conditions for breeding are favorable at this site, special attention will be given to this site during the biennial survey.

ts-7, located in a recharge basin, was found to be suitable as a breeding site, especially as the area will be constantly under water. As conditions for breeding are favorable, special attention will be given to this site during the biennial survey.

ts-11 was found to be suitable as a breeding site. Special attention will be given to this site during the biennial survey.

ts-12 is within a wetland area and was found to be suitable as a breeding site. Special attention will be given to this site during the biennial survey.

ts-A4 was found to be suitable as a breeding site. Special attention will be given to this site during the biennial survey.

ts-A6a, ts-A6b and ts-A6c are all recharge basins receiving coolant water from facilities. There was no evidence of tiger salamander activity. No action is recommended at this time.

ts-W2 is located adjacent to TS-14 (confirmed site), indicating that this water body could be suitable as a breeding site. Special attention will be given to this site during the biennial survey.

ts-W5 is located adjacent to TS-W6b (confirmed site), indicating that this water body could be suitable as a breeding site. Special attention will be given to this site during the biennial survey.

ts-W6a is in a wetland area shaded by a dense tree canopy. The area contains a man-made channel and pool area, as well as a naturally occurring vernal pool. Adult salamander presence is questionable, however, egg masses and larvae occurrence indicated that tiger salamander use this wetland. Special attention will be given to this site during the biennial survey.

\subsection{Reporting}

Beginning with calendar year 1998, the Environmental Services program will prepare an annual summary report of activities undertaken as a result of this plan. Highlights of that report will be included in the annual Site Environmental Report. Copies of this report will be made available to interested stakeholders upon request. 


\section{ATTACHMENT B Protection of Species of Special Concern}

\subsection{Introduction}

As indicated earlier, the banded sunfish (Enneacanthus obesus, see photo in Figure 5) has a "Special Concern" status with the New York State. It is not, however, in any protection category with the Federal government. The reason for "Special Concern" status is that the only remaining population of the banded sunfish is located in eastern Long Island and it is considered to be vulnerable to adverse environmental impacts. The habitat of the banded sunfish is primarily in slow water areas within lakes, ponds, and backwaters of streams and rivers (Breeder, 1936). Their preferred substrate is sand or mud, and other preferred areas are often shallow with vegetation over detritus-laden bottoms. Vegetation in this area is dense enough to maintain a viable habitat for the banded sunfish. Breeding and feeding habits on-site indicate that males build and guard small nests in sand among aquatic vegetation, while some females spawn as yearlings in June and July, when summer temperatures are $73-80^{\circ} \mathrm{F}$. Adults feed on aquatic insects, like midge larvae, as well as small invertebrates.

\subsection{Protection or Enhancement of the Banded Sunfishes' Habitat}

The current water- and vegetation-conditions in the Peconic River on-site support the requirements for successful habitation by banded sunfish, as observed during the biannual exploratory and routine sampling of fauna by BNL/NYSDEC. The primary impacts on such habitats have been predominantly natural. For example, lower than normal rainfall followed by extended drought conditions has contributed to lowering of the water table, leading to decreased water-flow in the river. Given the above characteristics of the habitat of the banded sunfish, protection of the banded sunfish is based on the following:

- Eliminating, reducing, or controlling pollutant discharges. Discharges to the Peconic River are evaluated for pollution control at the source, as opposed to pollution control at the discharge point into the Sewage Treatment Plant (STP) or the recharge basins. BNL has a pollution prevention/process evaluation program which evaluates sources and develops and implements implement pollution prevention measures. Periodic reports are prepared on the pollution prevention program and progress.

- Upgrading of the STP (a $\$ 8,000,000$ project) improved the treatment process (primary to secondary), reduced nitrogen loading in the Peconic River, and eliminated the use of chlorine as a disinfectant. (Full implementation of this project was completed in 1998).

- Maintaining an active environmental monitoring program for discharges to the river. Monitoring for organic, inorganic, radiological and biological parameters is conducted, in accordance with the State Pollutant Discharge Elimination System (SPDES) Permit. Figure 6 depicts the locations of the monitoring stations. Effluent limitations in the permit are based upon a Class $\mathrm{C}$ receiving water quality, which is based upon the protection of fish populations. The Whole Effluent Toxicity testing program has demonstrated that the discharges meet stringent requirements for protecting fish populations.

- Ensuring that adequate flow of the river is maintained within areas currently identified as banded sunfish habitats (especially within the area from the STP outfall to about 500 feet from the old site boundary - Station HM). This is achieved through routine observation of the river flow as part of the monitoring program. Stormwater can be added or recharge basin water diverted to maintain adequate flow, if needed, following approval from the NYSDEC. If discharges were to be 
eliminated or reduced in favor of groundwater discharge, a requirement to evaluate and address any major changes to the banded sunfish habitat will be imposed by NYSDEC during the permitting process. Creating deep pools at Station HM and HQ (Figure 6), so that adequate volume of water is available to enable small fish, like the banded sunfish, to survive during droughts.

- Ensuring that existing vegetation in the sunfish habitat area is not disturbed. This is accomplished by reviewing all activities that are proposed in the Peconic River on-site. If the selected environmental-restoration remedy for the contaminated sediment in the Peconic River is excavation and removal, the extent and duration of any disturbance will be minimized as much as possible and the habitat should be restored when the project is completed.

- Continued monitoring of the banded sunfish population by routine biannual sampling of the river in cooperation with the NYSDEC's Fisheries Branch. Population counts and age determinations (scale readings) are made during the above sampling surveys.

- Reducing potential predator species; for example, pickerel and largemouth bass are removed during the biannual fish-sampling program. A record of the number of pickerel and largemouth bass taken is logged at each sampling event to determine the success of controlling predators.

- Ensuring that on-going remediation efforts do not have an unacceptable impact on habitats. It is anticipated that the Peconic River may undergo a significant cleanup. A remedial system design is in progress involving proposals to dredge the sediment on-site to remove contaminants. The final decision has not been made. However, it is understood that any remedial action must consider the impact on the flora and fauna of the Peconic River, and that the habitat of the banded sunfish will be factored into the final assessment of the cleanup operation.

There are no asphalt roads in the vicinity of the sunfish habitat area, nor is there any large-scale vehicular road traffic in this area. A wide firebreak is the only road in the vicinity and any traffic is minimal, therefore the need to protect the Peconic River (and thus the banded sunfish habitat) from road salt and/or pesticide application is not necessary. 
Figure 5: Banded Sunfish (NYS - Listed "Special Concern” Species)

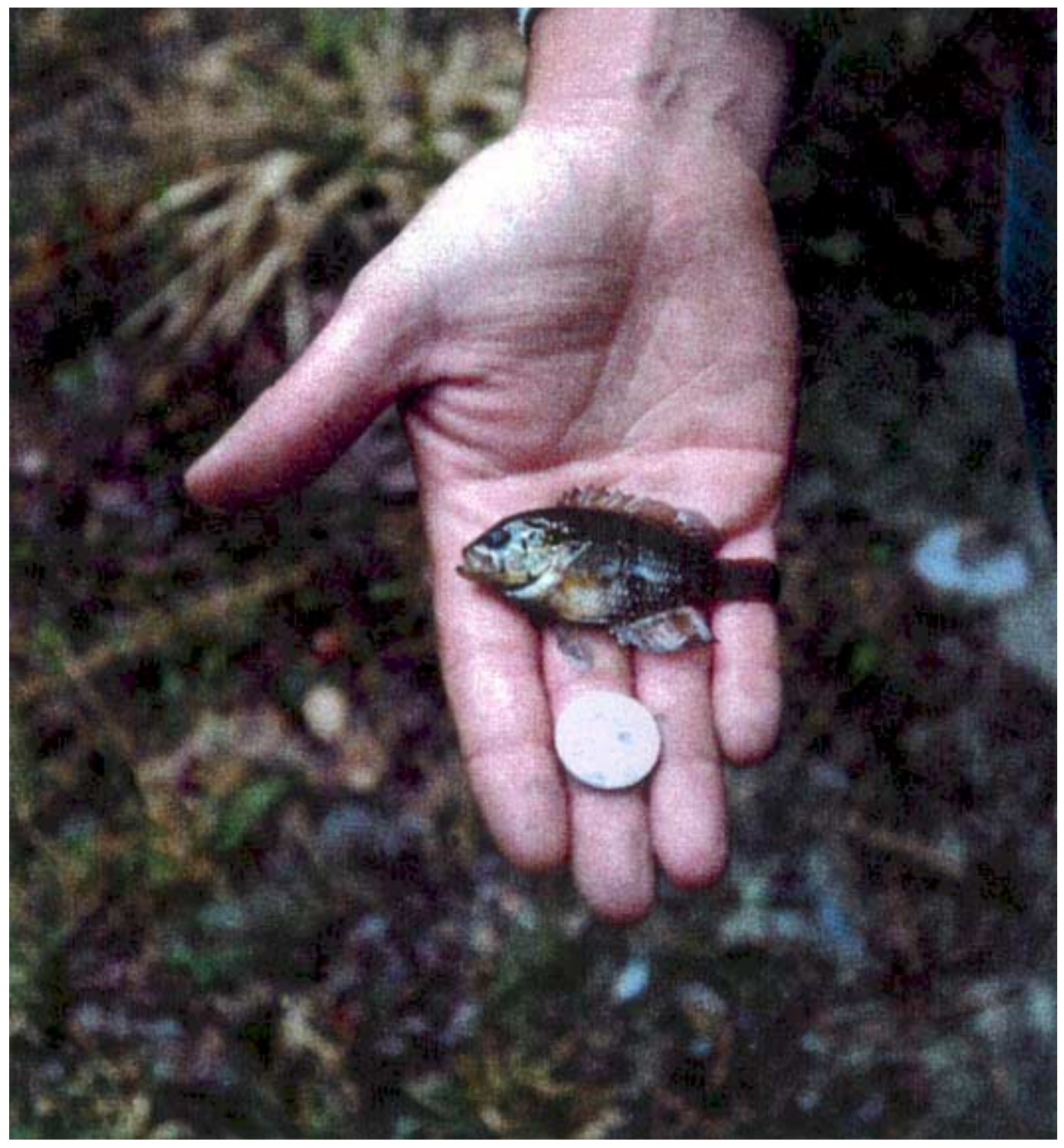


Figure 6: Peconic River Monitoring Stations

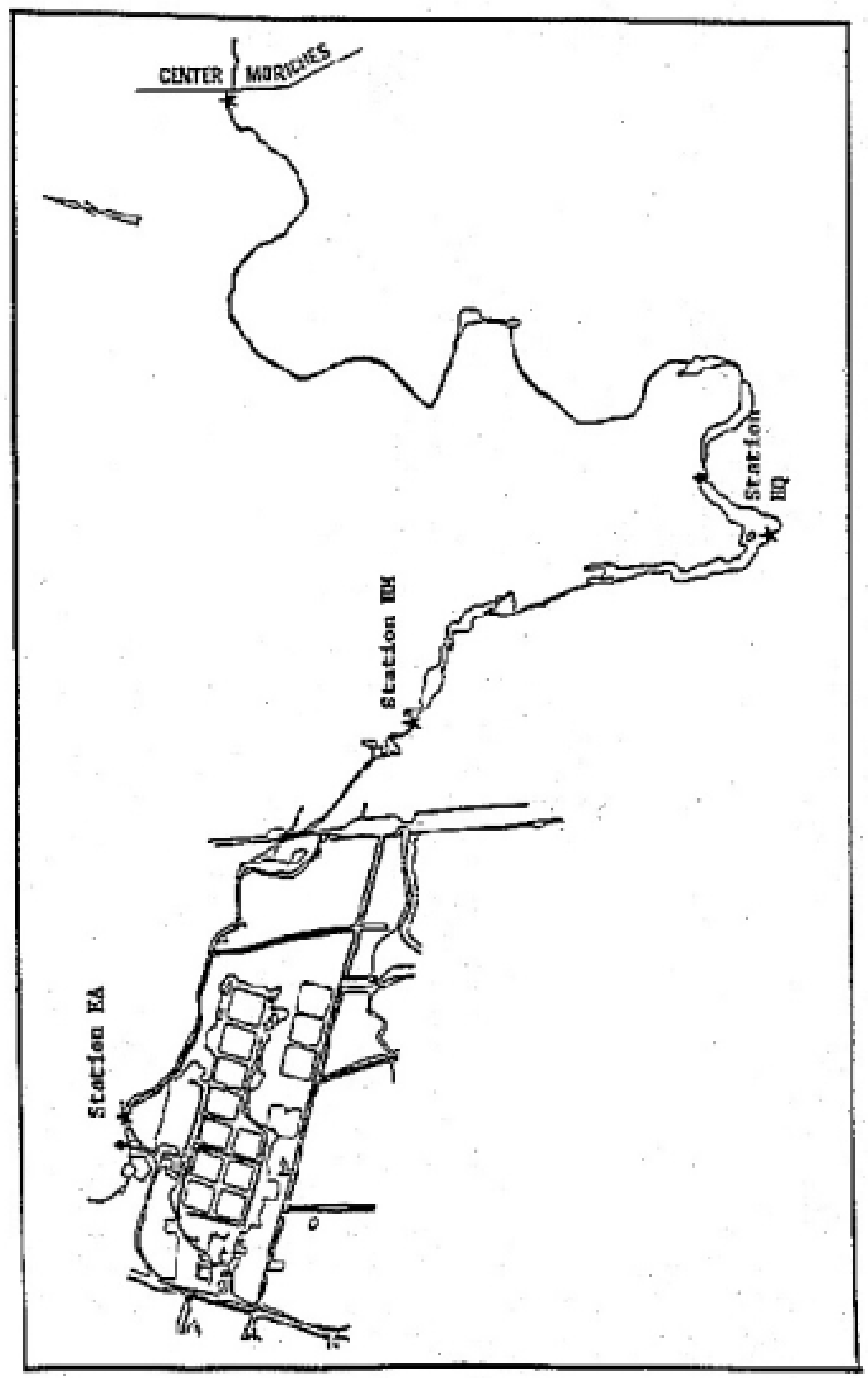




\section{ATTACHMENT C}

\section{Wildlife Management Plan - Action Items}

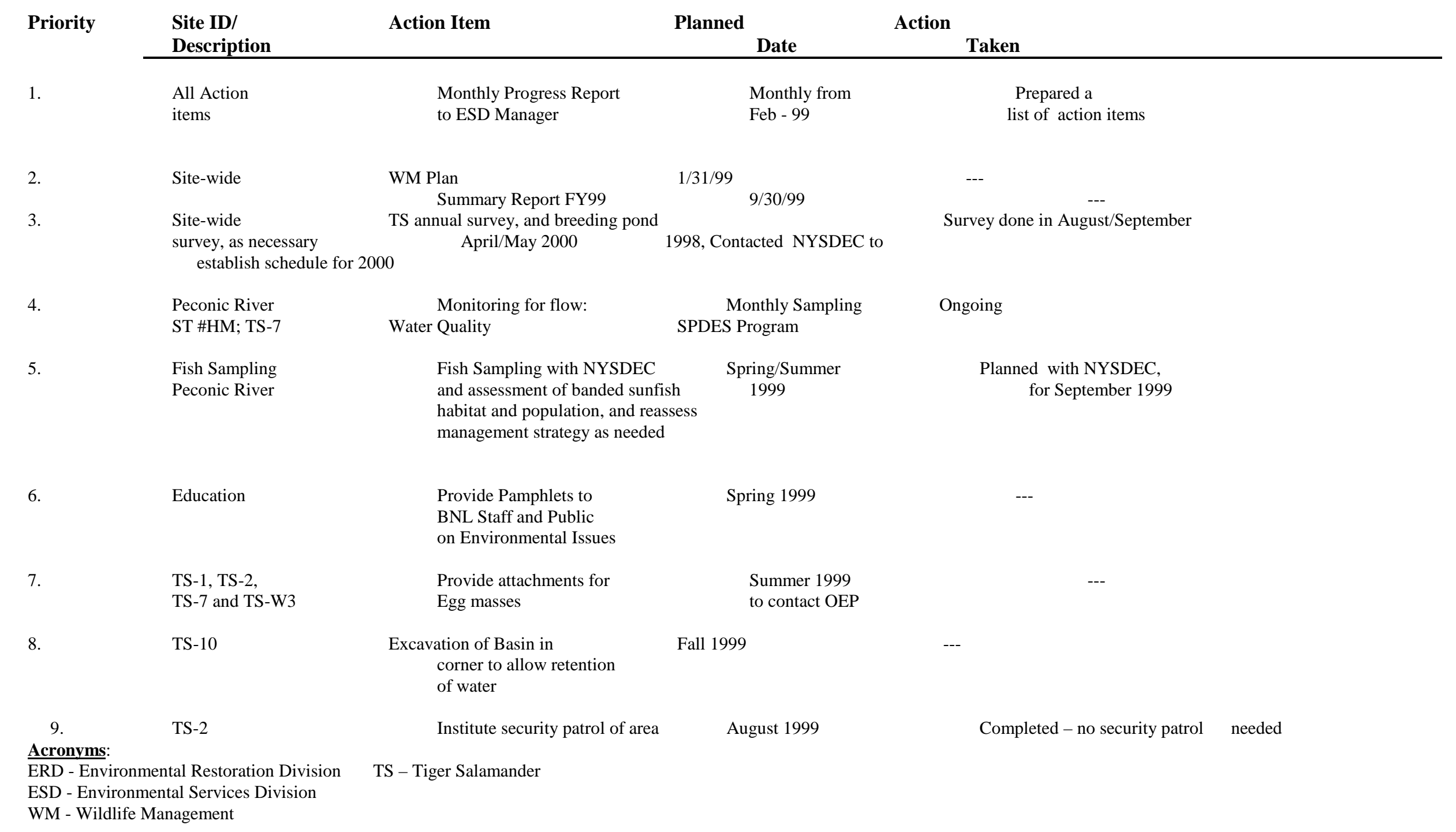




\section{ATTACHMENT C}

Wildlife Management Plan - Action Items

(continued)

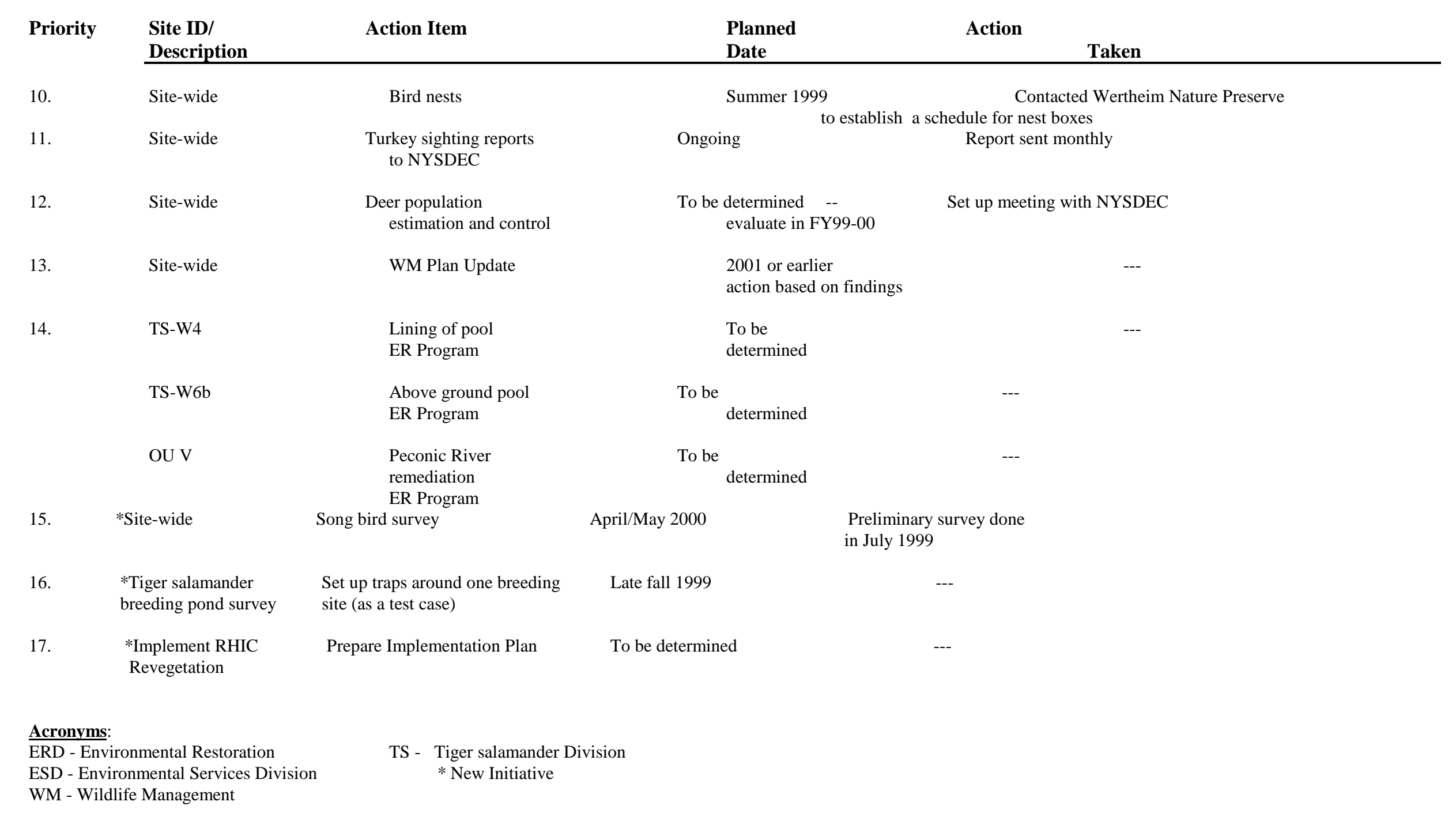


ATTACHMENT D 
ATTACHMENT D (continued) 
DISTRIBUTION LIST:

J. Baier, SCDHS

K. Brog, BNL

R. Corwin, PBC

R. Cowan, NYSDECE. Flores, ESD/BNL

G. Granzen, DOE/BHG

A. Harvey, DOE/CHEPG

R. Lee, ESD/BNL

J. Lister, NYSDEC/Albany

M. Logan, EPA

G. Malosh, DOE/BHG

J. McDougal, NYSDEC

W. Medeiros, ERD/BNL

J. Meersman, ERD/BNL

E. Murphy, PE/BNL

J. Naidu, ESD/BNL

G. Penny, DOE/BHG

M. Schlender, BNL

R. Simeone, DOE/BHG

T. Sperry, ESD/BNL 